\title{
Absorptive interactions of concurrent oral administration of $(+)$-catechin and puerarin in rats and the underlying mechanisms
}

\author{
Hui-fang SU, Qing LIN, Xin-yi WANG, Yao FU, Tao GONG, Xun SUN, Zhi-rong ZHANG*
}

Key Laboratory of Drug Targeting and Drug Delivery Systems, Ministry of Education, West China School of Pharmacy, Sichuan University, Chengdu 610041, China

\begin{abstract}
Aim: (+)-Catechin and puerarin are polyphenol and flavonoid, respectively, in green tea and foodstuffs. They exhibit potent antioxidant activity and are widely used for treating cardiocerebrovascular diseases. The aim of this work was to investigate the potential interactions between (+)-catechin and puerarin following concurrent oral administration in rats, and their absorption mechanisms in Caco-2 cell monolayers.

Methods: Pharmacokinetic studies were conducted in male rats received (+)-catechin (140 mg/kg, po) and/or puerarin (200 mg/kg, po). The cell uptake and transport behavior in Caco-2 cell monolayers and the interactions of the two compounds were analyzed.

Results: When (+)-catechin and puerarin were administered concurrently, the $\mathrm{AUC}_{0-12 \mathrm{~h}}$ and $C_{\max }$ values of puerarin were 2.48 -fold and 3.91-fold, respectively, as large as those of puerarin alone; the $\mathrm{AUC}_{0-12 \mathrm{~h}}$ and $\mathrm{C}_{\max }$ values of (+)-catechin were decreased to $57.62 \%$ and $77.55 \%$, respectively, compared with those of (+)-catechin alone. In Caco-2 cell monolayers, (+)-catechin (300 and $600 \mu \mathrm{mol} / \mathrm{L})$ significantly increased the cell uptake and transport of puerarin, whereas puerarin (300 and $600 \mu \mathrm{mol} / \mathrm{L})$ significantly decreased the cellular uptake and transport of (+)-catechin. Furthermore, both cyclosporine A (P-glycoprotein inhibitor) and MK-571 (MRP-2 inhibitor) significantly increased the cellular uptake and transport of (+)-catechin and puerarin.

Conclusion: Concurrent oral administration of $(+)$-catechin and puerarin significantly increased the absolute oral bioavailability of puerarin, but decreasing that of (+)-catechin. The competitive efflux of (+)-catechin and puerarin by P-glycoprotein and MRP-2 might lead to this interaction during their absorption process in the small intestine.
\end{abstract}

Keywords: (+)-catechin; puerarin; TCM; drug-drug interaction; pharmacokinetics; oral absorption; Caco-2 cell monolayer; cyclosporine A; MK-571

Acta Pharmacologica Sinica (2016) 37: 545-554; doi: 10.1038/aps.2015.164; published online 14 Mar 2016

\section{Introduction}

$(+)$-Catechin $[(+)-C$, Figure $1 \mathrm{~A}]$, which is one of the major active components of green tea and edible plants ${ }^{[1]}$, displays the strongest antioxidant activity during human low-density lipoprotein (LDL) oxidation compared with other polyphenols ${ }^{[2]}$. It has been reported that the cytoprotective activity of catechins is mainly due to their radical-scavenging properties and iron-chelating effects in vivo ${ }^{[3]}$. Puerarin (Pue, Figure 1B) is a type of an isoflavone derivative and the main active ingredient of the Pueraria lobata (Willd) Ohwi root ${ }^{[4]}$. Pue can significantly lower blood sugar levels, decrease serum total cholesterol and improve ocular blood flow in clinical applications ${ }^{[5-9]}$. Pue can also increase CYP7A1 mRNA expression, which reduced

\footnotetext{
* To whom correspondence should be addressed.

E-mail zrzzl@vip.sina.com

Received 2015-09-02 Accepted 2015-12-07
}

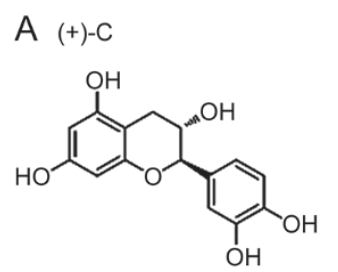

B Pue<smiles>O=c1c(-c2ccc(O)cc2)coc2c(C3OC(O)C(O)C(O)C3O)c(O)ccc12</smiles>

Figure 1. Chemical structures of (+)-Catechin and Puerarin. (A) (+)-Catechin, (B) Puerarin.

the atherogenic properties of dietary cholesterol in rats ${ }^{[6]}$.

In adults, the total flavonoid intake is approximately 1-200 $\mathrm{mg} /$ day $^{[10]}$. (+)-C and Pue, which are a polyphenol and a flavonoid, respectively, are mainly distributed in green tea and foodstuffs that are derived from pueraria. In our daily life, 
green tea and pueraria are consumed widely in daily diets; therefore, it is predictable that co-administration of $(+)-\mathrm{C}$ and Pue appear in dietary situations ${ }^{[11,12]}$. (+)-C and Pue have numerous pharmacological and pharmacokinetics properties in common. They both have potent antioxidant activity, which allows them to scavenge free radicals, they are widely used for the treatment of cardiocerebrovascular diseases ${ }^{[13-15]}$, they are readily metabolized by certain enzymes, and they can undergo methylation, glucuronidation and sulfation in $v_{i v o}{ }^{[16,17]}$. Although both (+)-C and Pue showed poor oral bioavailability when individually administered at a single dose ${ }^{[18,19]}$, co-administration of both drugs achieved enhanced therapeutic effects. Songlingxuemaikang Capsule ${ }^{\circledast}$, which is a type of traditional Chinese medicine (TCM) compound preparation that is utilized for the treatment of some cardiocerebrovascular diseases and hypertension in clinical applications ${ }^{[20]}$, mainly contains Pinus massoniana Lamb needle and Pueraria lobata (Willd) Ohwi root extracts, the bioactive substances of which are (+)-C and Pue ${ }^{[21,22]}$.

When drugs are co-administered to patients, drug-druginteractions (DDIs) play important roles in the pharmacokinetics of the drugs ${ }^{[23]}$, especially in the oral absorption of polyphenols and flavonoids. For example, piperine, an alkaloid derived from black pepper, has preventive activities against glucuronidation and (-)-Epigallocatechin-3-gallate (EGCG), which is the major catechin component of green tea that is utilized for cancer prevention. When piperine and EGCG were orally administered concurrently to rats, piperine enhanced the plasma $C_{\max }$ and area under the curve (AUC) values of EGCG by $1.3-$ fold $^{[24]}$. Additionally, Baba et al suggested that $(+)-C$ and (-)-epicatechin (another type of catechin) might be competitively absorbed in the gastrointestinal tract when coadministered ${ }^{[25]}$, and Jiang et al reported that when Pue and gastrodin (one of the main components of Tian-ma in TCM) were concurrently administered, the oral bioavailability of Pue was 10.7-fold higher than that in the Pue-only group ${ }^{[26]}$. However, no studies regarding the oral absorptive interactions of (+)-C and Pue following concurrent administration to rats have been reported, and the absorption mechanism of these two compounds when co-administered in vitro remains to be elucidated.

Thus, to investigate the oral absorptive interaction of $(+)-C$ and Pue, both (+)-C and Pue were orally administered concurrently to rats, and their pharmacokinetic behaviors were studied. The underlying absorptive mechanism was investigated with the human colonic Caco-2 cell line.

\section{Materials and methods}

\section{Chemicals and reagents}

(+)-Catechin (CAS: 154-23-4, batch № 131019, chemical purity $>98 \%$ ) and puerarin (CAS: 3681-99-0, batch № 131018, chemical purity $>99 \%$ ) were provided by Chengdu Jinzhe Biotech Co Ltd (Chengdu, China). The Caco-2 cell line and trypsin-0.02\% EDTA solution were obtained from Nanjing KeyGen Biotech Co Ltd (Nanjing, China). Fetal bovine serum (FBS) and Dulbecco's modified Eagle's medium (DMEM) were obtained from Gibco Laboratories (Invitrogen Co, NY, USA). Hank's balanced salt solution (HBSS, $\mathrm{pH}$ 7.4) was purchased from Beijing Solarbio Science \& Technology Co Ltd (Beijing, China). Cyclosporine A was obtained from Aladdin Chemistry Co Ltd (Shanghai, China). MK-571 was obtained from Sigma-Aldrich (St Louis, MO, USA). All other utilized reagents were of analytical grade.

\section{LC-MS/MS determination of (+)-C and Pue}

In this study, we used liquid chromatography equipped with tandem mass spectrometry (LC-MS/MS) to determine the $(+)-\mathrm{C}$ and Pue in the samples. The LC-MS/MS system consisted of a rapid resolution liquid chromatography system (1200 series, Agilent Technologies, Santa Clara, CA, USA) that was equipped with an SL auto-sampler, degasser and SL binary pump. An Agilent 6140 triple-quadrupole mass spectrometer with an electrospray ionization (ESI) interface was controlled using B01.03 software (1200 series, Agilent Technologies, Santa Clara, CA, USA) for qualitative analysis and B01.04 software (1200 series, Agilent Technologies, Santa Clara, CA, USA) for quantification. A Diamonsil ODS column $(100 \mathrm{~mm} \times 4.6 \mathrm{~mm}, 3 \mu \mathrm{m})$ coupled with a corresponding guard column (ODS, $5 \mu \mathrm{m}$ ) was used for the chromatographic separation. The mobile phase consisted of (A) $0.1 \%(v / v)$ aqueous formic acid and (B) acetonitrile, and the flow rate was 0.4 $\mathrm{mL} / \mathrm{min}$. The ESI was operated in negative ion mode to detect $(+)-\mathrm{C}$ and positive ion mode to detect Pue. The $[\mathrm{M}-\mathrm{H}]^{+}$at $\mathrm{m} / \mathrm{z}$ 289 of $(+)-\mathrm{C}$ and the $[\mathrm{M}+\mathrm{H}]^{+}$at $m / z 417$ of Pue were selected as the monitored ion. The lower limits of quantification (LLOQ) of (+)-C and Pue were $10 \mathrm{ng} / \mathrm{mL}$ and $5 \mathrm{ng} / \mathrm{mL}$, respectively. The precision levels of $(+)-C$ and Pue were both less than $9 \%$ of the coefficient of variation (RSD\%), and the accuracy levels of $(+)-\mathrm{C}$ and Pue were no more than $10 \%$ of the relative error (RE\%). The retention times of (+)-C and Pue were 1.47 and $1.36 \mathrm{~min}$, respectively. The chromatograms of (+)-C and Pue are shown in Supplementary Figure S1.

\section{Pharmacokinetics study and data analysis Animal performance}

Male Sprague-Dawley (SD) rats $(250 \pm 20 \mathrm{~g})$ were obtained from the Laboratory Animal Center of Sichuan University (Chengdu, China). The Sichuan University Animal Ethics Committee (Chengdu, China) approved the study protocol.

Rats were maintained in an environmentally controlled room with a temperature of $25 \pm 3{ }^{\circ} \mathrm{C}$, a humidity of $55 \% \pm 5 \%$ and a $12 \mathrm{~h}$ dark/light cycle. The rats were given free access to water, were acclimatized to the facilities for one week and were fed with a laboratory rodent chow until $12 \mathrm{~h}$ prior to the administration. During the experiments, 15 male rats were randomly divided into three groups ( 5 rats each). The rats were orally administered (po) $140 \mathrm{mg} / \mathrm{kg}(+)-C$ only, 200 $\mathrm{mg} / \mathrm{kg}$ Pue only, or $(+)-\mathrm{C}(140 \mathrm{mg} / \mathrm{kg})$ and Pue $(200 \mathrm{mg} / \mathrm{kg})$ concurrently. The $(+)-C$ and Pue were suspended in a $0.5 \%$ CMC-Na aqueous solution with concentrations of $17.5 \mathrm{mg} / \mathrm{mL}$ and $25 \mathrm{mg} / \mathrm{mL}$, respectively. Three hundred microliters of blood were collected from the orbital vein into heparinized 
tubes before and after receiving a single oral administration dose of (+)-C or/and Pue at fixed times of 0.05, 0.16, 0.25, 0.33, $0.5,1,2,4,6,8,10$ and $12 \mathrm{~h}$.

Meanwhile, 15 SD rats were randomly divided into three groups (5 rats each). The rats were intravenously administered (iv) $70 \mathrm{mg} / \mathrm{kg}(+)-\mathrm{C}$ only, $100 \mathrm{mg} / \mathrm{kg}$ Pue only, or (+)-C $(70 \mathrm{mg} / \mathrm{kg})$ and Pue $(100 \mathrm{mg} / \mathrm{kg})$ concurrently. Both the (+)-C and Pue were dissolved in normal saline (NS, $0.9 \% \mathrm{NaCl}$ ) with $20 \%$ ethyl alcohol. Three hundred microliters of blood was collected from the orbital vein into heparinized tubes before and after receiving a single intravenous administration dose of $(+)$-C or Pue at fixed times of $0.05,0.16,0.25,0.33,0.5,1,2,4,6$, 8,10 and $12 \mathrm{~h}$. The blood samples were centrifuged at $2000 \times g$ for $5 \mathrm{~min}$, and then $100 \mu \mathrm{L}$ of plasma supernatant was collected into 1.5-mL Eppendorf tubes. The plasma samples were stored at $-20^{\circ} \mathrm{C}$ until they were analyzed.

\section{Sample preparation}

Three hundred microliters of acetonitrile was added to $100 \mu \mathrm{L}$ plasma and vortex-mixed for $3 \mathrm{~min}$. After centrifugation at $13500 \times \mathrm{g}$ for $15 \mathrm{~min}$, the supernatant was collected and filtered through a $0.22 \mu \mathrm{m}$ microfiltration membrane (Tianjin Navigator Lab Instrument Co Ltd, Tianjin, China). A 1- $\mu \mathrm{L}$ aliquot was injected into the LC-MS/MS system for analysis.

\section{Data analysis}

Drug and Statistics Software (DAS 3.0; Mathematical Pharmacology Professional Committee of China, Shanghai, China) was used to analyze the plasma (+)-C and Pue concentrations over time in each experimental rat. The results were generated for several pharmacokinetic parameters, including the $\mathrm{AUC}_{0-\mathrm{t}}$ (area under the plasma drug concentration-time curve), $C_{\max }$ (the maximum plasma concentration), $T_{\max }$ (the time needed to reach the maximum plasma concentration) and the $\mathrm{MRT}_{0-\mathrm{t}}$ (the mean residence time) analyzed from 0 to $12 \mathrm{~h}$ after oral or intravenous administration to the male SD rats. The absolute oral bioavailability $\left(\mathrm{F}_{\mathrm{ab}}\right)$ was calculated as in Eq (1):

$$
\mathrm{F}_{\mathrm{ab}}=\mathrm{AUC}_{\mathrm{po}} \times \mathrm{D}_{\mathrm{iv}} / \mathrm{AUC}_{\mathrm{iv}} \times \mathrm{D}_{\mathrm{po}}
$$

$\mathrm{AUC}_{\mathrm{po}}$ was the $\mathrm{AUC}_{0-\mathrm{t}}$ via oral administration, $\mathrm{AUC}_{\mathrm{iv}}$ was the $\mathrm{AUC}_{0-\mathrm{t}}$ via intravenous administration, $\mathrm{D}_{\mathrm{iv}}$ was the intravenous administration dosage, and $\mathrm{D}_{\mathrm{po}}$ was the oral administration dosage.

\section{Cell culture}

Caco- 2 cells were cultured in DMEM supplemented with 10\% FBS, 1\% non-essential amino acids, $5 \mathrm{mmol} / \mathrm{L}$ L-glutamine and penicillin-streptomycin (10 000 units/mL penicillin; $10000 \mu \mathrm{g} / \mathrm{mL}$ streptomycin) at $37{ }^{\circ} \mathrm{C}$ in a $\mathrm{CO}_{2}$ incubator (SANYO, Osaka, Japan) with a humidified atmosphere of 5\% $\mathrm{CO}_{2}$. Caco-2 cells were seeded at a density of $4 \times 10^{4}$ cells $/ \mathrm{cm}^{2}$ and grown in $75-\mathrm{cm}^{2}$ culture plastic plates (Nest Biotech Co Ltd, Shanghai, China). After the Caco-2 cells became 80\%-90\% confluent, they were passaged following trypsinization with $0.25 \%$ trypsin containing $0.02 \%$ EDTA. The Caco-2 cells used in this study were between passages 30 and 40 .

\section{Cell uptake studies}

In the cell uptake experiments, Caco- 2 cells were seeded at a density of $5 \times 10^{4}$ cells $/ \mathrm{cm}^{2}$ in 12 -well cell culture plates (Nest Biotech Co Ltd, Shanghai, China). Culture medium was replaced every $2 \mathrm{~d}$ for the first week and then changed every day. On the 14 th day, the Caco-2 cells were used for cell uptake experiments. Stock solutions of (+)-C (300 $\mathrm{mmol} / \mathrm{L})$ and/or Pue (300 mmol/L) were dissolved in HBSS. Fresh culture medium was added $24 \mathrm{~h}$ before the cell uptake experiments. One hour before the uptake experiments, culture medium was removed, and the growing cell surface was gently washed twice with HBSS that was pre-warmed to $37^{\circ} \mathrm{C}$. During the uptake experiments, Caco- 2 cells that were cultured in 12-wells cell culture plates were incubated at $37^{\circ} \mathrm{C}$ incubator for $1 \mathrm{~h}$. After the incubation period, drugcontaining HBSS was removed, and ice cold HBSS was added to terminate the cell uptake. The cell monolayers were quickly washed three times with ice cold HBSS. After the addition of ultrapure water, Caco-2 cells were lysed by three freeze and thaw cycles so that the cells were completely ruptured. The ruptured cell suspensions were collected, and $10 \mu \mathrm{L}$ of each suspension was used for total protein quantification with a BCA assay (Nanjing KeyGEN Biotech Co Ltd, Nanjing, China). Meanwhile, $100 \mu \mathrm{L}$ of each suspension was withdrawn and then added to $300 \mu \mathrm{L}$ of acetonitrile for protein precipitation. Cell uptake $(\mu \mathrm{g} / \mu \mathrm{g})$ was calculated by normalizing the amount of (+)-C and/or Pue ( $\mu \mathrm{g})$ divided by the total protein content $(\mu \mathrm{g})$.

\section{Time- and concentration-dependent uptake of (+)-C and Pue}

To investigate the time-dependent cell uptake behavior of (+)-C and Pue, $1 \mathrm{~mL}$ of HBSS containing $400 \mu \mathrm{mol} / \mathrm{L}(+)-\mathrm{C}$ or $400 \mu \mathrm{mol} / \mathrm{L}$ Pue was added to the cell culture plate wells and incubated at $37^{\circ} \mathrm{C}$ for $0.5,1,1.5$ and $2 \mathrm{~h}$. To observe the concentration-dependent cellular uptake behavior, $1 \mathrm{~mL}$ of HBSS containing (+)-C (200, 300, 400, 600 and $800 \mu \mathrm{mol} / \mathrm{L})$ and Pue $(100,200,400,600$ and $800 \mu \mathrm{mol} / \mathrm{L})$ were added to the cell culture plate wells and incubated at $37^{\circ} \mathrm{C}$ for $1 \mathrm{~h}$. The subsequent procedure was the same as described in the cell uptake study section.

\section{Effects of P-gp/MRP-2 inhibitors on the cellular uptake of (+)-C and Pue}

Caco-2 cells were pre-incubated in HBSS containing a P-gp inhibitor (10 $\mathrm{mmol} / \mathrm{L}$ cyclosporine A) and an MRP-2 inhibitor $(50 \mu \mathrm{mol} / \mathrm{L} \mathrm{MK}-571)$ at $37^{\circ} \mathrm{C}$ for $30 \mathrm{~min}$. Then, (+)-C (300 $\mu \mathrm{mol} / \mathrm{L})$ or Pue $(300 \mu \mathrm{mol} / \mathrm{L})$ was added to the wells and incubated for $1 \mathrm{~h}$. The subsequent procedure was the same as that described in the cell uptake study section.

\section{Mutual effect of (+)-C and Pue on cell uptake}

Three hundred micromolar (+)-C was used in the (+)-C-only group, and similarly, $300 \mu \mathrm{mol} / \mathrm{L}$ Pue was used in the Pueonly group. (+)-C (300 $\mu \mathrm{mol} / \mathrm{L})$ and Pue (300 or $600 \mu \mathrm{mol} / \mathrm{L})$ were co-administered in the $(+)-C$ concurrently treated groups, whereas Pue $(300 \mu \mathrm{mol} / \mathrm{L})$ and $(+)-C$ (300 or 600 
$\mu \mathrm{mol} / \mathrm{L})$ were co-administered in the Pue concurrently treated groups. Then, the cells were incubated at $37^{\circ} \mathrm{C}$ for $1 \mathrm{~h}$. The subsequent procedures were carried out as described in the cell uptake study section.

\section{(+)-C and Pue transport across Caco- 2 cell monolayers}

Caco-2 cells were seeded in 12-well Costar Transwell plate inserts (Corning Incorporated, NY, USA) at a density of $1 \times 10^{5}$ cells $/ \mathrm{cm}^{2}$ in $0.5 \mathrm{~mL}$ DMEM media. Twenty-one days postseeding, the Caco- 2 cells in the 12-well Costar Transwell plates were used for the cell transport experiments. The transepithelial electrical resistance (TEER) values, a reference for the integrity of Caco-2 cell monolayers, were assessed with a Millicell-ERS apparatus (ERS0002, Millipore, USA). When the TEER values exceeded $800 \mathrm{~cm} \cdot \Omega$, the inserts were ready for use in the experiment. Before the transport experiment, prewarmed HBSS was used to gently wash the Caco- 2 cell monolayers twice. Then, the transport experiments were performed by adding the solutions to either the apical ( $\mathrm{AP}, 0.5 \mathrm{~mL}$ ) or the basolateral (BL, $1.5 \mathrm{~mL}$ ) sides. During the experiments, cell monolayers were incubated at $37^{\circ} \mathrm{C}$ and placed in a thermostated shaking incubator (TaiCang Experimental Equipment Factory, TaiCang, China) at a speed of 50 rounds per minute. After the samples settled, $200 \mu \mathrm{L}$ solutions were sampled from the receiving chamber (BL side or AP side) and immediately replaced with $200 \mu \mathrm{L}$ of $37^{\circ} \mathrm{C}$ fresh HBSS. The collected samples were placed in centrifuge tubes and kept at $-80^{\circ} \mathrm{C}$ until analysis. To determine the (+)-C and Pue concentrations, the samples were added to the same volume of acetonitrile and vortex-mixed for $3 \mathrm{~min}$. After centrifugation at $15300 \times \mathrm{g}$ for $10 \mathrm{~min}, 1 \mu \mathrm{L}$ of the supernatant was subjected to LC-MS/MS analysis.

The apparent permeability coefficient $\left(P_{\mathrm{app}}, \mathrm{cm} / \mathrm{s}\right)$ and apparent permeability ratio (PDR) values were calculated by $\mathrm{Eq}(2)$ and Eq (3), respectively.

$$
P_{\text {app }}=(d Q / d t) / A \times C_{0}
$$

$d Q / d t$ ( $\mathrm{mmol} / \mathrm{L} / \mathrm{s})$ was the change in the receiving chamber concentration over time, $A$ was the surface area of the cell insert membrane $\left(1.12 \mathrm{~cm}^{2}\right)$, and $C_{0}(\mu \mathrm{g} / \mathrm{mL})$ was the initial concentration of $(+)-C$ or Pue in the donor chamber $(\mathrm{mmol} / \mathrm{L})$.

$$
\mathrm{PDR}=P_{\text {app BL } \rightarrow \mathrm{AP}} / P_{\text {app AP } \rightarrow \mathrm{BL}}
$$

$P_{\text {app BL } \rightarrow \text { AP }}$ Was the $P_{\text {app }}$ of the basolateral side to the apical side, and $P_{\text {app AP } \rightarrow \mathrm{BL}}$ was the $P_{\text {app }}$ of the apical side to the basolateral side.

\section{Time- and concentration-dependent transport of (+)-C across} Caco-2 cell monolayers

To observe the time-dependent transport behavior of $(+)-C$, $0.5 \mathrm{~mL}$ HBSS containing $400 \mu \mathrm{mol} / \mathrm{L}(+)-C$ was added to the AP side, and it was incubated for $0.5,1,1.5$ and $2 \mathrm{~h}$ in a thermostated shaking incubator $\left(37^{\circ} \mathrm{C}, 50\right.$ rounds per minute). After it was incubated for the fixed times, $200 \mu \mathrm{L}$ solutions were sampled from the BL side and $200 \mu \mathrm{L}$ fresh $\mathrm{HBSS}\left(37^{\circ} \mathrm{C}\right)$ was added as a replacement. To observe the concentrationdependent transport behavior of (+)-C, $0.5 \mathrm{~mL}$ HBSS solutions containing various concentrations of (+)-C (200, 300, 400, 600 or $800 \mu \mathrm{mol} / \mathrm{L})$ were added to the AP side and incubated for $1 \mathrm{~h}$ in a thermostated shaking incubator (50 rounds per minute, $\left.37^{\circ} \mathrm{C}\right)$. After $1 \mathrm{~h}, 200 \mu \mathrm{L}$ of solution was sampled from the BL side and $200 \mu \mathrm{L}$ fresh $\operatorname{HBSS}\left(37^{\circ} \mathrm{C}\right)$ was added as a replacement. The subsequent procedures were kept the same as described in the cellular transport study section.

\section{Mutual effect of (+)-C and Pue on transcellular transport}

$(+)-C$ was only added onto the AP side at a concentration of $300 \mu \mathrm{mol} / \mathrm{L}$ in the (+)-C-only group. Pue $(300 \mu \mathrm{mol} / \mathrm{L})$ was added only onto the AP side in the Pue-only group. (+)-C (300 $\mu \mathrm{mol} / \mathrm{L}$ ) and Pue (300 or $600 \mu \mathrm{mol} / \mathrm{L})$ mixtures were added onto the AP side in the concurrently $(+)-C$ treated groups, whereas Pue $(300 \mu \mathrm{mol} / \mathrm{L})$ and (+)-C (300 or $600 \mu \mathrm{mol} / \mathrm{L})$ mixtures were added onto the AP side in the concurrently Pue treated groups. Then, the cells were incubated for $1 \mathrm{~h}$ in a thermostated shaking incubator $\left(37^{\circ} \mathrm{C}, 50\right.$ rounds per minute), and a $200 \mu \mathrm{L}$ of solution was sampled from the BL side. The subsequent procedures were carried out as described in the cellular transport study section.

\section{Effect of P-gp/MRP-2 inhibitors on (+)-C and Pue transport}

Caco- 2 cells that were cultured in 12-well Costar transwell plates were pre-incubated in HBSS containing a P-gp inhibitor $(10 \mu \mathrm{mol} / \mathrm{L}$ cyclosporine A) and a MRP inhibitor $(50 \mu \mathrm{mol} / \mathrm{L}$ $\mathrm{MK}-571$ ) at $37^{\circ} \mathrm{C}$ for $30 \mathrm{~min}$. After pre-incubation for $30 \mathrm{~min}$, (+)-C (300 mmol/L-300 $\mathrm{mmol} / \mathrm{L})$ or Pue $(300 \mathrm{mmol} / \mathrm{L}-300$ $\mu \mathrm{mol} / \mathrm{L})$ were spiked in the AP or BL sides and then incubated for another $1 \mathrm{~h}$. The subsequent procedures were kept the same as described in the cellular transport study section.

\section{Statistical analysis}

The statistical significance of the differences of the means among the groups was evaluated by using the two-tailed paired Student's $t$ test with a significant level of $P<0.05$.

\section{Results}

\section{Mutual influence of (+)-C and Pue on oral absorption}

The plasma concentration-time profiles are displayed in Figure 2. The main pharmacokinetic parameters of $(+)-C$ and Pue are summarized in Tables 1 and 2. The $\mathrm{AUC}_{0-12 \mathrm{~h}}(9.29$ $\mathrm{mg} / \mathrm{L} \cdot \mathrm{h}), C_{\max }(4.19 \mathrm{mg} / \mathrm{L})$ and $\mathrm{F}_{\mathrm{ab}} 5.27 \%$ of Pue in the group that was co-administered with (+)-C were 2.48-fold, 3.91fold and 2.51-fold, respectively, greater than that of Pue alone $\left(\mathrm{AUC}_{0-12 \mathrm{~h}} 3.74 \mathrm{mg} / \mathrm{L} \cdot \mathrm{h}, \mathrm{C}_{\max } 1.07 \mathrm{mg} / \mathrm{L}\right.$ and $\mathrm{F}_{\mathrm{ab}} 2.1 \%$ ). By contrast, the $\mathrm{AUC}_{0-12 \mathrm{~h}}(1.74 \mathrm{mg} / \mathrm{L} \cdot \mathrm{h}), \mathrm{C}_{\max }(0.76 \mathrm{mg} / \mathrm{L})$ and $\mathrm{F}_{\mathrm{ab}}$ $2.23 \%$ of the $(+)-C$ group that was co-administered with Pue were decreased to $57.62 \%, 77.55 \%$ and $52.59 \%$, respectively, compared with that of $(+)-C$ alone $\left(\mathrm{AUC}_{0-12 \mathrm{~h}} 3.02 \mathrm{mg} / \mathrm{L} \cdot \mathrm{h}, \mathrm{C}_{\max }\right.$ $0.98 \mathrm{mg} / \mathrm{L}$ and $\mathrm{F}_{\mathrm{ab}} 4.24 \%$ ).

\section{Caco- 2 cell uptake}

\section{Time- and concentration-dependent uptake of (+)-C and Pue}

As shown in Figure 3, the cell uptake of (+)-C and Pue increased in the concentration (100-800 $\mu \mathrm{mol} / \mathrm{L})$ and time 

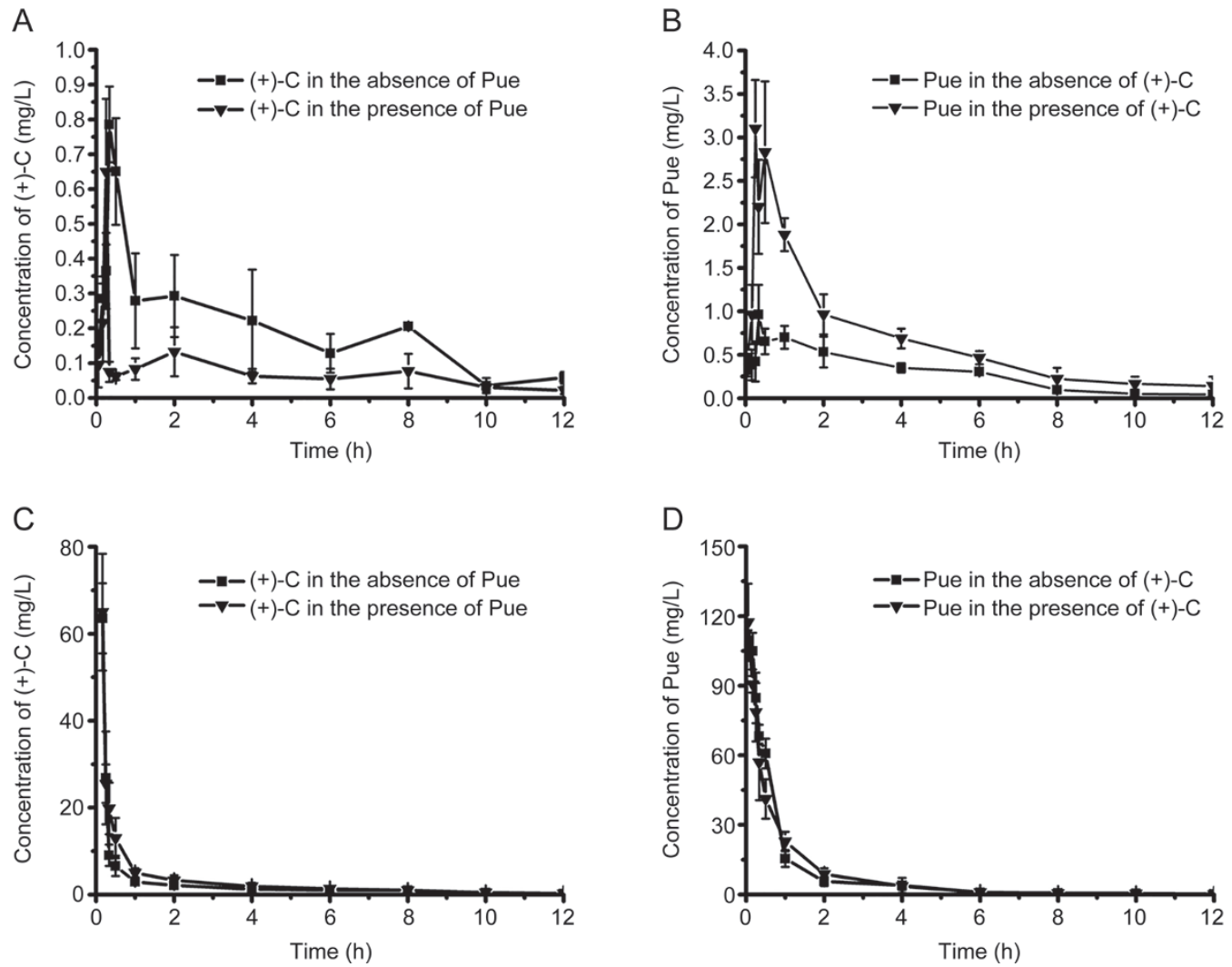

Figure 2. Plasma concentration-time profiles of (+)-C and Pue. (A) (+)-C (140 mg/kg, po, in the presence or absence of Pue). (B) Pue (200 mg/kg, po, in the presence or absence of $(+)-C)$. (C) $(+)-C(70 \mathrm{mg} / \mathrm{kg}$, iv, in the presence or absence of Pue). (D) Pue (100 mg/kg, iv, in the presence or absence of $(+)-C)$. Data represent mean \pm SD. $n=5$.

Table 1. Pharmacokinetic parameters of $(+)-C$ in plasma.

\begin{tabular}{|c|c|c|c|c|}
\hline Parameters & $(+)$-C-only $(p o)$ & $(+)-C+$ Pue $(p o)$ & (+)-C-only (iv) & (+)-C+Pue (iv) \\
\hline $\mathrm{AUC}_{0-12 \mathrm{~h}}(\mathrm{mg} / \mathrm{L} \cdot \mathrm{h})$ & $3.02 \pm 0.70$ & $1.74 \pm 0.72^{\mathrm{b}}$ & $35.30 \pm 5.44$ & $43.87 \pm 4.99$ \\
\hline$T_{\max }(\mathrm{h})$ & $0.25 \pm 0.068$ & $0.33 \pm 0.19$ & 0.05 & 0.05 \\
\hline$C_{\max }(\mathrm{mg} / \mathrm{L})$ & $0.98 \pm 0.33$ & $0.76 \pm 0.32$ & $88.24 \pm 19.65$ & $80.85 \pm 10.35$ \\
\hline $\mathrm{F}_{\mathrm{ab}}(\%)$ & $4.24 \pm 0.35$ & $2.23 \pm 0.55^{c}$ & NA & NA \\
\hline
\end{tabular}

Note: Data represent mean $\pm S D(n=5)$. NA, not applicable.

Compared to (+)-C (po)-only, ${ }^{\mathrm{b}} \mathrm{P}<0.05 ;{ }^{\mathrm{c}} \mathrm{P}<0.01$.

Table 2. Pharmacokinetic parameters of Pue in plasma.

\begin{tabular}{|c|c|c|c|c|}
\hline Parameters & Pue-only (po) & $\mathrm{Pue}+(+)-\mathrm{C}(p o)$ & Pue-only (iv) & $\mathrm{Pue}+(+)-\mathrm{C}$ (iv) \\
\hline $\mathrm{AUC}_{0-12 \mathrm{~h}}(\mathrm{mg} / \mathrm{L} \cdot \mathrm{h})$ & $3.74 \pm 1.20$ & $9.29 \pm 2.36^{c}$ & $91.04 \pm 11.88$ & $91.66 \pm 9.61$ \\
\hline $\mathrm{MRT}_{0-12 \mathrm{~h}}(\mathrm{~h})$ & $3.41 \pm 0.41$ & $3.18 \pm 0.63$ & $1.17 \pm 0.38$ & $1.24 \pm 0.32$ \\
\hline$T_{\max }(\mathrm{h})$ & $0.49 \pm 0.29$ & $0.47 \pm 0.32$ & 0.05 & 0.05 \\
\hline$C_{\max }(\mathrm{mg} / \mathrm{L})$ & $1.07 \pm 0.39$ & $4.19 \pm 2.25^{b}$ & $109.61 \pm 4.34$ & $117.33 \pm 16.61$ \\
\hline $\mathrm{F}_{\mathrm{ab}}(\%)$ & $2.10 \pm 0.39$ & $5.27 \pm 0.91^{\mathrm{c}}$ & NA & NA \\
\hline
\end{tabular}

Note: Data represent mean $\pm \mathrm{SD}(n=5)$. NA, not applicable.

Compared to Pue (po)-only, ${ }^{\mathrm{b}} P<0.05 ;{ }^{\mathrm{c}} P<0.01$. 

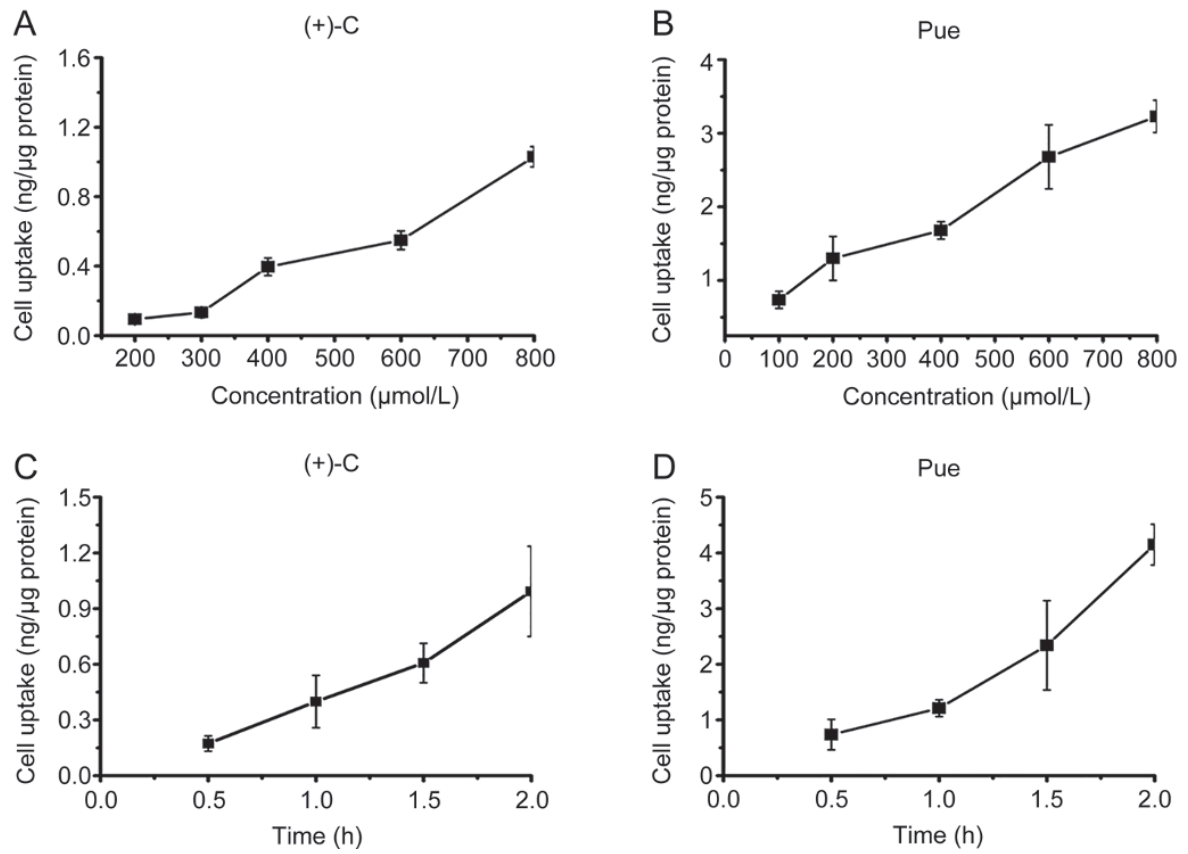

Figure 3. Cell uptake of (+)-C and Pue. (A) Concentration-dependent cell uptake of (+)-C. (B) Concentration-dependent cell uptake of Pue. (C) Timedependent cell uptake of $(+)-C(400 \mu \mathrm{mol} / \mathrm{L})$. (D) Time-dependent cell uptake of Pue $(400 \mu \mathrm{mol} / \mathrm{L})$. Data are presented as mean \pm SD. $n=3$.

\section{$(0.5-2 \mathrm{~h})$ test ranges.}

\section{Mutual effect of (+)-C and Pue on cell uptake}

The cellular uptake of (+)-C alone was 1.2 and 0.65 times, respectively, greater than in the groups co-administered 300 or $600 \mu \mathrm{mol} / \mathrm{L}$ Pue (Figure 4A). Additionally, the cellular uptake of Pue alone was 1.4 times and 1.08 times, respectively, smaller than that in the group co-administered with 300 or 600 $\mu \mathrm{mol} / \mathrm{L}(+)-\mathrm{C}$ at $60 \mathrm{~min}$ (Figure 4B).

\section{Role of P-gp/MRP-2 inhibitors in (+)-C and Pue uptake}

Cyclosporine A and MK-571 significantly increased the cellular uptake of (+)-C to 2.83 and 1.92 times, respectively, compared with the (+)-C alone group. Additionally, they increased the cellular uptake of Pue to 5.45- and 1.64-fold, respectively, compared with the Pue alone group (Figures 4C and 4D).

\section{Transport studies}

Time- and concentration-dependent transport of (+)-C

We found that $(+)-C$ increased almost linearly in the time (0.5-2 $\mathrm{h})$ and concentration test ranges $(200 \mu \mathrm{mol} / \mathrm{L}-1$ $\mathrm{mmol} / \mathrm{L}$ ) (Figure 5).

\section{Mutual effect of (+)-C and Pue on transport}

The $P_{\text {app }(\mathrm{AP} \rightarrow \mathrm{BL})}$ values of the $(+)$-C-only group were decreased to approximately $47.6 \%$ and $52.3 \%$, respectively compared with that of the $(+)-C$ group that was co-treated with Pue $(300$ or $600 \mu \mathrm{mol} / \mathrm{L}$ ) (Figure 6A). The $P_{\text {app (AP } \rightarrow \mathrm{BL})}$ values of the Pueonly group were increased to approximately 206\% and 258\%, respectively compared with that of the Pue groups that were co-treated with (+)-C (300 or $600 \mu \mathrm{mol} / \mathrm{L})$ (Figure 6B).
The effect of P-gp/MRP-2 inhibitors on the absorptive and efflux transport of (+)-C and Pue

In the presence of MK-571, the combined (+)-C and Pue $P_{\text {app (AP } \rightarrow \mathrm{BL})}$ value significantly increased compared with the single treatment groups (Table 3 and 4). Additionally, cyclosporine A significantly increased the Pue $P_{\text {app (AP } \rightarrow B L)}$ value and decreased the (+)-C $P_{\text {app (BL } \rightarrow \text { AP) }}$ value significantly. The (+)-C and Pue PDR were both more than 1.5 times, and cyclosporine A and MK-571 both decreased the PDR of these two compounds significantly.

\section{Discussion}

The aim of the current study was to elucidate the potential oral absorptive interactions between (+)-C and Pue when concurrently administered. In the present work, $(+)-C$ and Pue were simultaneously administered to rats orally, and the AUC and $C_{\max }$ of Pue in mixed groups increased compared with the Pueonly group. However, compared with the (+)-C-only group, the AUC and $C_{\max }$ of (+)-C decreased when co-administered orally with Pue. Several reasons might contribute to explain this phenomenon, such as the competitive absorption in the gastrointestinal tract of rats ${ }^{[25]}$ and the competitive metabolism in vivo ${ }^{[27]}$. In this work, we mainly focused on the competitive absorption and efflux effect between $(+)-C$ and Pue when orally administered concurrently.

In the cell uptake study, the uptake of Pue $(300 \mu \mathrm{mol} / \mathrm{L})$, when it was concurrently administered with (+)-C (300 or 600 $\mu \mathrm{mol} / \mathrm{L})$, was greater than that in the Pue-only treatment. Additionally, Pue (300 or $600 \mu \mathrm{mol} / \mathrm{L}$ ) significantly decreased the uptake of $(+)-C(300 \mu \mathrm{mol} / \mathrm{L})$. These results were consistent with the animal experiment results and revealed that the 
A

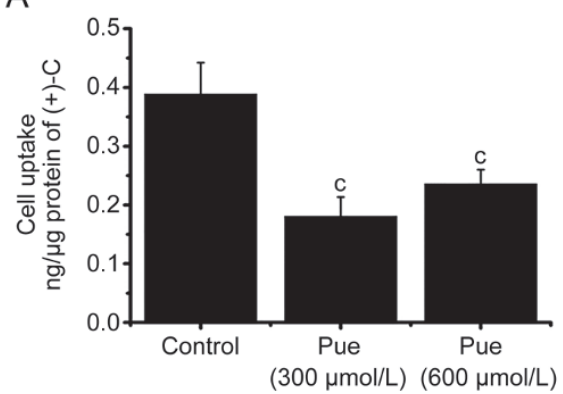

C

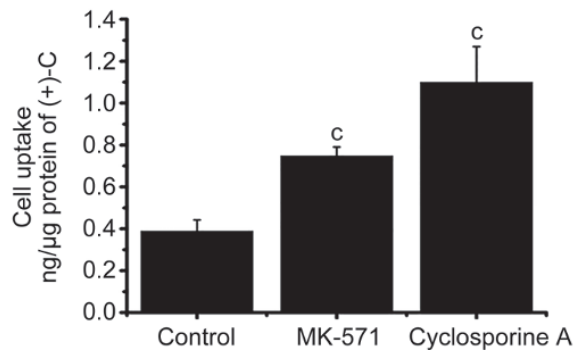

B

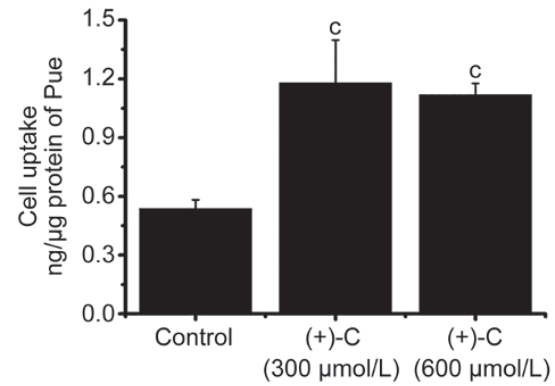

D

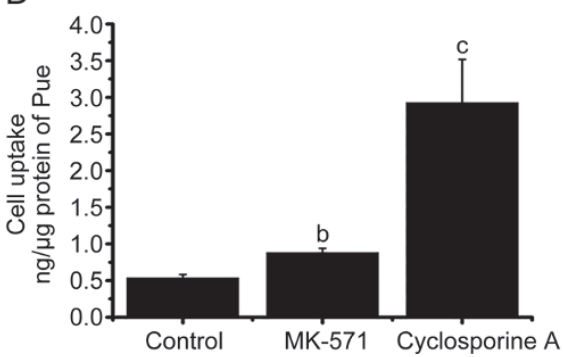

Figure 4. Cell uptake interaction and influences of efflux protein inhibitors on cell uptake of (+)-C and Pue. (A) Effect of Pue (300 or $600 \mu m o l / L)$ on the cell uptake of (+)-C in 60 min. (B) Effect of (+)-C (300 or $600 \mu \mathrm{mol} / \mathrm{L})$ on the cell uptake of Pue in 60 min. (C) The effect of P-glycoprotein inhibitors and MRP-2 inhibitors on the cell uptake of (+)-C. (D) The effect of P-glycoprotein inhibitors and MRP-2 inhibitors on the cell uptake of Pue in 60 min. Data represent mean \pm SD. $n=3 .{ }^{b} P<0.05,{ }^{c} P<0.01$ versus control.
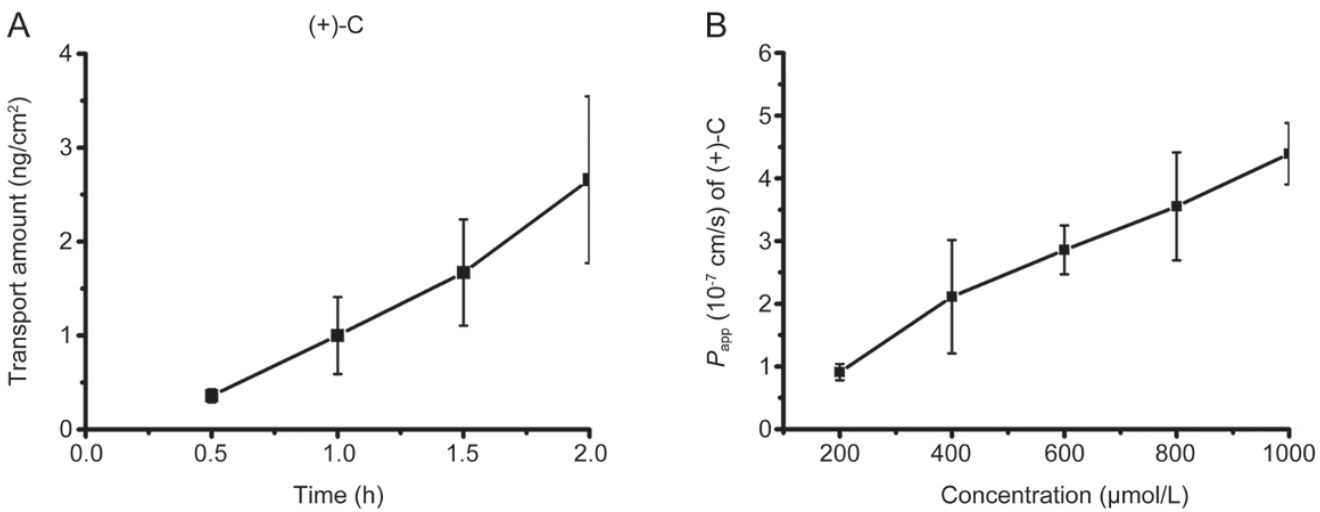

Figure 5. Cell transport of (+)-C. (A) The transport amount of $(+)-\mathrm{C}(400 \mu \mathrm{mol} / \mathrm{L})$ across Caco- 2 cell monolayers over time. (B) Concentration-dependent transport rate of $(+)-\mathrm{C}$ across $\mathrm{Caco}-2$ cell monolayers.
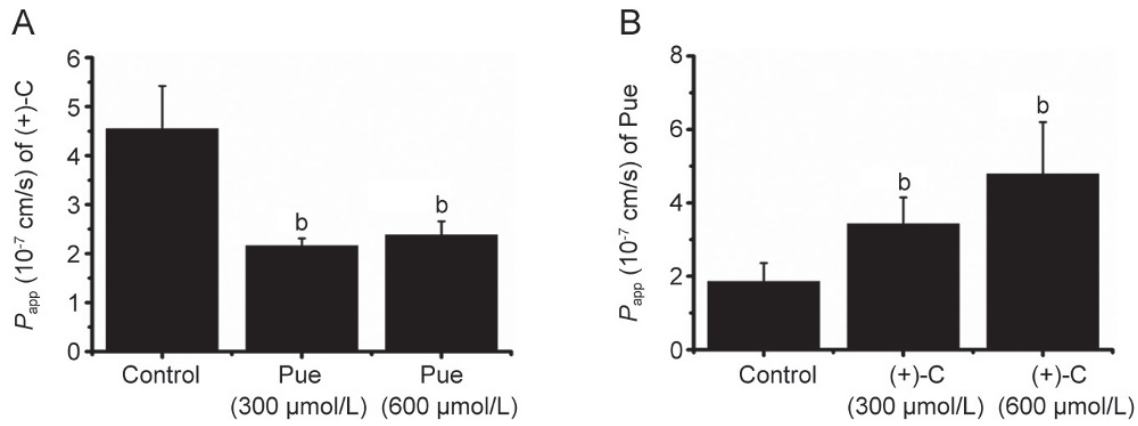

Figure 6. Cell transport interaction of (+)-C and Pue. (A) Effect of Pue (300 or $600 \mu \mathrm{mol} / \mathrm{L})$ on the transport of $(+)-\mathrm{C}$ at $60 \mathrm{~min}$. (B) Effect of (+)-C (300 or $600 \mu \mathrm{mol} / \mathrm{L})$ on the transport of Pue at $60 \mathrm{~min}$. Data represent mean \pm SD. $n=3$. ${ }^{\mathrm{b}} P<0.05$ versus control. 
Table 3. The effect of P-gp/MRP-2 inhibitors on the transport of (+)-C across Caco-2 cell monolayers at 60 min.

\begin{tabular}{|c|c|c|c|}
\hline \multirow[t]{2}{*}{ Group } & \multicolumn{3}{|c|}{$P_{\text {app }}\left(10^{-7} \mathrm{~cm} / \mathrm{s}\right)$} \\
\hline & $\mathrm{AP} \rightarrow \mathrm{BL}$ & $\mathrm{BL} \rightarrow \mathrm{AP}$ & PDR \\
\hline$(+)-C 300 \mu \mathrm{mol} / \mathrm{L}$ & $4.55 \pm 0.88$ & $7.97 \pm 2.22$ & 1.75 \\
\hline (+)-C $300 \mu \mathrm{mol} / \mathrm{L}+10 \mu \mathrm{mol} / \mathrm{L}$ Cyclosporin A & $4.14 \pm 1.73$ & $2.57 \pm 0.31^{\mathrm{b}}$ & 0.62 \\
\hline (+)-C $300 \mu \mathrm{mol} / \mathrm{L}+50 \mu \mathrm{mol} / \mathrm{L}$ MK-571 & $9.14 \pm 1.13^{b}$ & $7.26 \pm 1.25$ & 0.79 \\
\hline
\end{tabular}

Note: Data represent mean \pm SD $(n=3)$.

Compared with (+)-C -only group, ${ }^{\mathrm{b}} \mathrm{P}<0.05$.

Table 4. The effect of P-gp/MRP-2 inhibitors on the transport of Pue across Caco-2 cell monolayers at 60 min.

\begin{tabular}{lcr}
\hline Group & & $P_{\text {app }}\left(10^{-6} \mathrm{~cm} / \mathrm{s}\right)$ \\
BL $\rightarrow$ AP & AP $\rightarrow$ BL & $5.22 \pm 0.55$ \\
PDR \\
Pue $300 \mu \mathrm{mol} / \mathrm{L}$ & $1.86 \pm 0.50$ & $12.11 \pm 3.19$ \\
Pue $300 \mu \mathrm{mol} / \mathrm{L}+10 \mu \mathrm{mol} / \mathrm{L}$ Cyclosporin A & $6.50 \pm 0.49^{\mathrm{c}}$ & $3.81 \pm 0.79^{\mathrm{b}}$ \\
Pue $300 \mu \mathrm{mol} / \mathrm{L}+50 \mu \mathrm{mol} / \mathrm{L}$ MK-571 & $6.59 \pm 0.62^{\mathrm{b}}$ & 1.86 \\
\hline
\end{tabular}

Note: Data represent mean $\pm \operatorname{SD}(n=3)$.

Compared with Pue-only group, ${ }^{\mathrm{b}} P<0.05 ;{ }^{\mathrm{c}} P<0.01$.

uptake interactions of (+)-C and Pue also existed in Caco-2 cell when co-administered. To explain this phenomenon, the cell uptake properties that were related to time and concentration were studied for the first time, and the results showed that the (+)-C and Pue uptake increased almost linearly with increasing time and concentration. This result illustrated that passive uptake might be the main pathway for these two compounds in Caco-2 cells. By contrast, the effect of efflux protein transporters on the absorption of these compounds should also be considered, as König et al elucidated that P-gp and MRP-2 efflux transporters exert critical roles in drugdrug interactions ${ }^{[28]}$. In the current study, P-gp (cyclosporine A) and MRP-2 inhibitors (MK-571) significantly increased the cell uptake of $(+)-C$ and Pue, which suggested that these two compounds might be substrates of the P-gp and MRP-2 efflux pumps, which are involved in cell uptake, and when (+)-C and Pue are concurrently administered, the competition for the efflux pump might lead to a mutual effect on cell uptake.

However, after (+)-C and Pue are absorbed into enterocytes, how these two compounds travel across the basolateral membrane and into the blood remains unknown. Therefore, the transcellular transport interaction between $(+)-C$ and Pue was investigated. The apparent permeability coefficient $\left(P_{\text {app AP } \rightarrow \mathrm{BL}}\right)$ of Pue $(300 \mu \mathrm{mol} / \mathrm{L})$ when concurrently treated with (+)-C (300 and $600 \mu \mathrm{mol} / \mathrm{L}$ ) in mixed groups was increased to 2.06fold and 2.58-fold, respectively, compared with Pue-only. As for $(+)-C$, these values in the mixed groups were decreased to $47.5 \%$ and $52.3 \%$, respectively, compared with (+)-C-only. These findings were consistent with the cell uptake results, which indicated that in the process of absorption, a significant interaction between (+)-C and Pue actually occurred in the small intestine, and an underlying mechanism might be determined by the transport characteristics of these two compounds when they are co-administered. Liang et al previously revealed that the transport properties of Pue were time- and concentration-dependent, which illustrated that passive transport might be the main pathway for Pue in Caco-2 cells ${ }^{[29]}$. In this study, we mainly focused on the transcellular transport properties of $(+)-C$, and this study is the first to demonstrate time and concentration effects on $(+)-C$ transport in Caco-2 cells. The results showed that $(+)-C$ transport increased almost linearly with increasing time and concentration, which implied that passive transportation played an important role in the transport process of (+)-C. Additionally, MK-571 significantly increased the $P_{\text {app }(\mathrm{AP} \rightarrow \mathrm{BL})}$ levels of $(+)-\mathrm{C}$ and Pue, whereas cyclosporine A significantly increased the Pue $P_{\text {app }(\mathrm{AP} \rightarrow \mathrm{BL})}$ levels and decreased the $(+)-C P_{\text {app }(\mathrm{BL} \rightarrow \mathrm{AP})}$, which showed that P-gp and MRP-2 both could affect the efflux transport of (+)-C and Pue. Song et al demonstrated that when the PDR value was more than 1.5, active transportation might be involved in the drug transport process ${ }^{[30]}$. In this study, the PDR values of these two compounds were both more than 1.5, indicating that efflux transportation might be involved in the transport processes. Additionally, when cyclosporin A or MK-571 were added into the AP or the BL sides, (+)-C and Pue PDR values were both decreased significantly. Liang et al revealed that P-gp or MRP drug-efflux pump inhibitors are involved in Pue transport, which would cause a decrease in its PDR ${ }^{[29]}$; thus, it was elucidated that P-gp and MRP-2 were involved in the transcellular transport of $(+)-C$ and Pue and that they are definitely substrates of these two drug-efflux pumps. Taken together, we provided evidence that (+)-C and Pue might be two competitive substrates of the MRP-2 and P-gp drug-efflux pumps, which led to their mutual influence when they were 
orally administered concurrently to rats. Kitagawa et al illuminated that different lipid solubilities and planar structures of drugs might lead to different affinities to MRP-2 and/or P-gp, and the stronger affinity of a drug to MRP-2 and P-gp is, the more it would be effluxed with P-gp- and MRP-2-mediated transport ${ }^{[31,32]}$. Accordingly, (+)-C might have a stronger affinity to MRP-2 and P-gp than Pue.

In the current study, we found that the underlying competitive efflux of (+)-C and Pue by P-gp and MRP-2 (drugefflux pump) might contribute to their potential interactions during their absorption into small intestine after concurrent oral (+)-C and Pue administration. However, numerous studies have shown that poloxamer 407 and TPGS could inhibit $\mathrm{P}-\mathrm{gp}^{[33]}$; therefore, further studies should give more attention to the nanoformulation of drugs that are loaded or mixed with poloxamer 407/TPGS to avoid the interplay between (+)-C and Pue.

\section{Conclusion}

In summary, the current study investigated the potential interaction between (+)-C and Pue when orally administered concurrently in vivo. Our results showed that after concurrent oral administration, (+)-C significantly increased the absolute oral bioavailability $\left(\mathrm{F}_{\mathrm{ab}}\right)$ of Pue while decreasing its own absolute oral bioavailability $\left(\mathrm{F}_{\mathrm{ab}}\right)$. The cellular uptake and transport study results in the Caco- 2 cell monolayers elucidated that competitive efflux of (+)-C and Pue by P-gp and MRP-2 (drug-efflux pump) might lead to the potential interactions during their absorption in the small intestine.

\section{Acknowledgements}

We are thankful for the financial support of the National S\&T Major Project of China (Grant No 2012ZX09304004001) and the National Natural Science Foundation of China (No 81473169).

\section{Author contribution}

Zhi-rong ZHANG and Hui-fang SU designed the research; Hui-fang SU performed the research; Zhi-rong ZHANG, Tao GONG, Xun SUN and Yao FU contributed new reagents or analytic tools; Hui-fang SU, Xin-yi WANG and Qing LIN analyzed the data; and Hui-fang SU wrote the paper.

\section{Supplementary information}

Supplementary Figure S1 is available at Acta Pharmacologica Sinica's website.

\section{References}

1 Mak JC. Potential role of green tea catechins in various disease therapies: progress and promise. Clin Exp Pharmacol Physiol 2012; 39: $265-73$.

2 Bell JR, Donovan JL, Wong R, Waterhouse AL, German JB, Walzem RL, et al. (+)-Catechin in human plasma after ingestion of a single serving of reconstituted red wine. Pharmacogn Rev 2000; 71: 103-8.

3 Morel I, Lescoat G, Cogrel P, Sergent O, Pasdeloup N, Brissot P, et al. Antioxidant and iron-chelating activities of the flavonoids catechin, quercetin and diosmetin on iron-loaded rat hepatocyte cultures.
Biochem Pharmacol 1993; 45: 13-9.

4 Li M. Pueraria lobata (Willd.) Ohwi (Gegen, Kudzu). Dietary Chinese Herbs: Springer; 2015. P 235-45.

5 Hsu FL, Liu IM, Kuo DH, Chen WC, Su HC, Cheng JT. Antihyperglycemic effect of puerarin in streptozotocin-induced diabetic rats. J Nat Prod 2003; 66: 788-92.

6 Yan LP, Chan SW, Chan AS, Chen SL, Ma XJ, Xu HX. Puerarin decreases serum total cholesterol and enhances thoracic aorta endothelial nitric oxide synthase expression in diet-induced hypercholesterolemic rats. Life Sci 2006; 79: 324-30.

7 Xuan B, Zhou YH, Yang RL, Li N, Min ZD, Chiou GC. Improvement of ocular blood flow and retinal functions with puerarin analogs. J Ocul Pharmacol Ther 1999; 15: 207-16.

8 Song $X$, Chen $P$, Chai X. Effects of puerarin on blood pressure and plasma renin activity in spontaneously hypertensive rat. Acta Pharmacol Sin 1988; 9: 55-8.

9 Benlhabib E, Baker JI, Keyler DE, Singh AK. Effects of purified puerarin on voluntary alcohol intake and alcohol withdrawal symptoms in $\mathrm{P}$ rats receiving free access to water and alcohol. J Med Food 2004; 7: 180-6.

10 Song Y, Manson JE, Buring JE, Sesso HD, Liu S. Associations of dietary flavonoids with risk of type 2 diabetes, and markers of insulin resistance and systemic inflammation in women: a prospective study and cross-sectional analysis. J Am Coll Nutr 2005; 24: 376-84.

11 Yang CS, Landau JM. Effects of tea consumption on nutrition and health. J Nutr 2000; 130: 2409-12.

12 Geng Z, Zongdao C, Yimin W. Physicochemical properties of lotus (Nelumbo nucifera Gaertn) and kudzu (Pueraria hirsute Matsum) starches. Inter J Food Sci Tech 2007; 42: 1449-55.

13 Rice-Evans CA, Miller NJ, Paganga G. Structure-antioxidant activity relationships of flavonoids and phenolic acids. Free Radical Bio Med 1996; 20: 933-56.

14 Tijburg L, Mattern T, Folts J, Weisgerber U, Katan M. Tea flavonoids and cardiovascular diseases: a review. Critl Rev Food Sci 1997; 37: 771-85.

15 Wan H, Zhu H, Tian M, Hu X, Yang J, Zhao C, et al. Protective effect of chuanxiongzine-puerarin in a rat model of transient middle cerebral artery occlusion-induced focal cerebral ischemia. Nucl Med Commun 2008; 29: 1113-22.

16 Guerra M, Speroni E, Broccoli M, Cangini M, Pasini P, Minghetti A, et al. Comparison between Chinese medical herb Pueraria lobata crude extract and its main isoflavone puerarin: antioxidant properties and effects on rat liver CYP-catalysed drug metabolism. Life Sci 2000; 67: 2997-3006.

17 Das N. Studies on flavonoid metabolism: Absorption and metabolism of (+)-catechin in man. Biochem Pharmacol 1971; 20: 3435-45.

18 Zhang QH, Wang WB, Li J, Chang YX, Wang YF, Zhang J, et al. Simultaneous determination of catechin, epicatechin and epicatechin gallate in rat plasma by LC-ESI-MS/MS for pharmacokinetic studies after oral administration of Cynomorium songaricum extract. J Chromatogr B Analyt Technol Biomed Life Sci 2012; 880: 168-71.

19 Zhao L, Liu A, Sun M, Gu J, Wang H, Wang S, et al. Enhancement of oral bioavailability of puerarin by polybutylcyanoacrylate nanoparticles. J Nanomater 2011; 2011: 6.

20 Wong J, Zheng Z. The clinical research of Song Ling Xue Mai Kang ameliorating the compliance and endothelial function of artery in hypertensive patients. J Tradit Chin Med Univ Hunan 2011; 8: 27.

21 Shen Z, Theander O. Flavonoid glycosides from needles of Pinus massoniana. Phytochemistry 1985; 24: 155-8.

22 Qiao HY, Zhu WL, Luo R, Ke ZH, Hao XF, Ke X, et al. UPLC fingerprint and components identification of Songling Xuemaikang capsules by 
LC-MS/MS. West China J Pharm Sci 2013; 1: 30.

23 Palleria C, Di Paolo A, Giofrè C, Caglioti C, Leuzzi G, Siniscalchi A, et al. Pharmacokinetic drug-drug interaction and their implication in clinical management. J Res Med Sci 2013; 18: 601-10.

24 Lambert JD, Hong J, Kim DH, Mishin VM, Yang CS. Piperine enhances the bioavailability of the tea polyphenol (-)-epigallocatechin-3-gallate in mice. J Nutr 2004; 134: 1948-52.

25 Baba S, Osakabe N, Natsume M, Muto Y, Takizawa T, Terao J. In vivo comparison of the bioavailability of (+)-catechin,(-)-epicatechin and their mixture in orally administered rats. J Nutr 2001; 131: 2885-91.

26 Jiang L, Dai J, Huang Z, Du Q, Lin J, Wang Y. Simultaneous determination of gastrodin and puerarin in rat plasma by HPLC and the application to their interaction on pharmacokinetics. J Chromatogr B Analyt Technol Biomed Life Sci 2013; 915-916: 8-12.

27 Manach C, Texier O, Morand C, Crespy V, Régérat F, Demigné C, et al. Comparison of the bioavailability of quercetin and catechin in rats. Free Radical Biol Med 1999; 27: 1259-66.

28 König J, Müller F, Fromm MF. Transporters and drug-drug interactions: important determinants of drug disposition and effects. Pharmacogn
Rev 2013; 65: 944-66.

29 Liang XL, Zhao L, Liao ZG, Zhao GW, Zhang J, Chao YC, et al. Transport properties of puerarin and effect of Radix Angelicae Dahuricae extract on the transport of puerarin in Caco-2 cell model. J Ethnopharmacol 2012; 144 : 677-82.

30 Song L, Zhang N, Xu DS. Absorption mechanism of paeoniflorin across Caco-2 monolayer model. Chin Tradit and Herbal Drugs 2008; 39: 41.

31 Wang R, Kuo C, Lien L, Lien E. Structure-activity relationship: analyses of P-glycoprotein substrates and inhibitors. J Clin Pharm Ther 2003; 28: 203-28.

32 Kitagawa S, Nabekura T, Takahashi T, Nakamura Y, Sakamoto H, Tano $\mathrm{H}$, et al. Structure-activity relationships of the inhibitory effects of flavonoids on P-glycoprotein-mediated transport in KB-C2 cells. Biol Pharm Bull 2005; 28: 2274-8.

33 Saxena V, Hussain MD. Poloxamer 407/TPGS mixed micelles for delivery of gambogic acid to breast and multidrug-resistant cancer. Int J Nanomed 2012; 7: 713-21. 